\title{
UNDERSTANDING BANK MONEY THROUGH A QUANTUM MACROECONOMIC THEORY OF CREDIT. SOME THEORETICAL CONSIDERATIONS ON MICROCREDIT
}

\author{
Marco Desogus, Dept. of Economics and Business Science, University of Cagliari, Italy
}

dx.doi.org/10.18374/JIFE-20-3.1

\begin{abstract}
Reframing risk assessments of microcredit, this paper expands on quantum macroeconomic conceptions of money, output and income to argue that production is endogenously financed.Building on the works of Schmitt, Cencini and Rossi, the conceptual logic of quantum monetary theory traces the origins of a (micro)firm's finances to its consequent production. Production is then a self-sustaining system, and (micro)firms should not, in fact, dependent on worthiness decision made by banks for credit and funding. With especial focus on microfinance (and microcredit specifically), the socio-economic system requires restructuring to accommodate understandings of production as endogenous and microcredit as sustainable. This includes reforming national accounting practices to accurately represent possibilities of insolvency, themselves much reduced by the recognition of production as endogenous.
\end{abstract}

Keywords: quantum-economics; theory of money emissions; economic system; financial intermediation; microcredit 